\title{
Dissertations and Theses Databases
}

This appendix provides a compilation of example dissertation and theses resources. The resources provided here are only a selection of resources. Some of these resources have been referred to throughout this book and are presented here for easy access. An * denotes mention of a commercial product; product endorsement is not intended.

There is no single resource for locating all dissertations and theses. There are international (e.g., Dissertation Abstracts International), national (e.g., Australian Digital Theses Program), and local university resources or repositories with dissertation and theses (e.g., Stanford University Compilation of Dissertations Resources). Note some theses or dissertations may not be published or available through normal publishing venues. There are commercial vendors (e.g., "Proquest Dissertation Express) where investigators can locate and order a full-text copy of a dissertation. Through the use of an Internet search engine, free dissertation resources are identifiable (e.g., Doctoral Research in Educational Technology: A Directory of Dissertations, 1977-2004).

Australasian Digital Theses Program

- https://www.caul.edu.au/programs-projects/past-programs/australasian-digital-theses Center for Research Libraries Foreign Dissertations

- https://www.crl.edu/collections

DART-Europe E-theses Portal (DEEP)

- www.dart-europe.org

Dissertation.com

- www.dissertation.com

Education Resources Information Center (ERIC)

- https://eric.ed.gov

EThOS from the British Library

- http://ethos.bl.uk

European Working Group of the Networked Digital Library of Theses and Dissertations (NDLTD)

- www.ndltd.org "LibGuides Community

- https://community.libguides.com

- Type dissertations or theses in the search box at the top of the web page to search for LibGuides from librarians with links to assist in finding local, national, and international dissertation and theses repositories.

Networked Digital Library of Theses and Dissertations (NDLTD)

- www.ndltd.org 


\section{Appendix D}

Open Access Theses and Dissertations Worldwide

- oatd.org

*Proquest Dissertation Express

- disexpress.umi.com

*Proquest Dissertations and Theses-United Kingdom and Ireland

- www.theses.com

Registry of Open Access Repositories (ROAR)

- http://roar.eprints.org

Theses Canada Portal

- https://www.bac-lac.gc.ca/eng/services/theses/Pages/theses-canada.aspx Thèses en Ligne (TEL)

- tel.archives-ouvertes.fr University of Miami Electronic Theses and Dissertations

- etd.library.miami.edu

Virginia Tech's Electronic Theses and Dissertations

- scholar.lib.vt.edu/theses

*WorldCat Dissertations and Theses

- Only available by subscription through the OCLC product called FirstSearch.

- The larger database of WorldCat is available for free and has an advanced search screen that allows investigators to limit the content to "thesis/dissertation." Here is the direct website address (www.worldcat.org/advancedsearch) to access the advanced search page in WorldCat. 